license

\title{
Akun Twitter BNPB_RI Sebagai Media Komunikasi Pemerintah Indonesia di Masa Pandemi Covid-19
}

\author{
Vindhi Putri Pratiwi ${ }^{1}$, Dian Eka Rahmawati ${ }^{2}$, Titin Purwaningsih ${ }^{3}$ \\ vindhiputripratiwi@gmail.com; dianekarahmawati93@gmail.com; titinpurwaningsih@umy.ac.id \\ ${ }^{1}$ Jusuf Kalla School of Government, Universitas Muhammadiyah Yogyakarta \\ ${ }^{2}$ Magister Ilmu Pemerintahan, Universitas Muhammadiyah Yogyakarta \\ ${ }^{3}$ Magister Ilmu Pemerintahan, Universitas Muhammadiyah Yogyakarta
}

DOI: $10.22219 /$ sospol.v7i2.16116

\begin{abstract}
The existence of the COVID-19 pandemic globally is a challenge in itself, especially for the Indonesian government. One of them is in the delivery of information related to COVID-19. The existence of this large pandemic also produces a variety of information that is able to create tension for the community. Therefore, there needs to be effective and appropriate government communication to the community related to this pandemic. So the purpose of this study is to look at government communication in the pandemic period through@BNPB_Indonesia Twitter account by knowing the intensity of government communication and looking at the interaction relationship of government communication through@BNPB_Indonesia Twitter account. This research uses qualitative research approach method and data analysis processed with the help of NVivo 12 Plus software. The data was obtained through@BNPB_indonesia Twitter account. From the results of the research obtained communication built by the government during the COVID-19 pandemic through Twitter accounts @BNPB_indonesia actively convey information to the public and the information can be received by the public well. So this sees government communication that is external which has the function to manage people.
\end{abstract}

\begin{abstract}
Abstrak
Adanya pandemi COVID-19 secara global menjadi tantangan sendiri khususnya bagi pemerintah Indonesia. Salah satunya dalam penyampaian informasi terkait dengan COVID-19. Adanya pandemi besar ini juga menghasilkan berbagai informasi-informasi yang mampu menciptakan ketegangan bagi masyarakat. Oleh karenanya perlu adanya komunikasi pemerintah yang efektif dan tepat kepada masyarakat terkait dengan pandemic ini. Sehingga tujuan penelitian ini untuk melihat komunikasi pemerintah di masa pandemi melalui akun Twitter@BNPB_Indonesia dengan mengetahui intensitas komunikasi pemerintah dan melihat hubungan interaksi komunikasi pemeirntah melalui akun Twitter @BNPB_Indonesia. Penelitian ini menggunakan metode pendekatan penelitian kualitatif dan analisis data diolah dengan bantuan software NVivo 12 Plus. Data diperoleh melalui akun Twitter @BNPB_indonesia. Dari hasil penelitian diperoleh komunikasi yang dibangun oleh pemerintah di masa pandemic COVID-19 melalui akun Twitter @BNPB_indonesia aktif menyampaikan informasi kepada public dan informasi tersebut dapat diterima oleh public dengan baik. Sehingga hal ini melihatkan komunikasi pemerintah yang bersifat eksternal dimana memiliki fungsi to managing people.
\end{abstract}

\section{Keywords}

COVID-19, Komunikasi

Pemerintah, Media Sosial, Twitter

\section{Article History}

Received March 29, 2021

Revised September 10, 2021

Accepted November 11, 2021

Published November 18, 2021

\section{Corresponding Author}

Vindhi Putri Pratiwi.

Universitas Muhammadiyah

Yogyakarta, Jl. Brawijaya,

Geblagan, Bantul, Daerah

Istimewa Yogyakarta. 55183. 


\section{Pendahuluan}

Perkembangan teknologi dan informasi di era digital semakin berkembang pesat. Hal ini juga akan mempengaruhi penggunaan TIK dalam proses komunikasi. Komunikasi merupakan proses pertukaran informasi antar dua orang atau lebih dan adanya aktifitas mengirim, menerima dan merespon pesan-pesan dari mereka yang melakukan interaksi (Erliana, 2014). Di era digital pada saat ini akan memberikan kemudahan dalam melakukan komunikasi dengan jarak jauh. Seperti yang dikatakan oleh (Anisa \& Rachmaniar, 2019) bahwasannya pada era digital akan mampu mengjangkau publik dengan luas dan heterogen, sehingga pemerintah dapat memanfatkan media digital untuk memberikan kemudahan akses dan kecepatan dalam melakukan interaksi dua arah kepada masyarakat.

Pemerintah sendiri juga membutuhkan komunikasi yang baik dalam menyampaikan proses kebijakan dari konsepsi hingga implementasi kebijakan (Gregory, 2006). Karena informasi yang disampaikan oleh pemerintah akan memberikan feedback dengan bentuk adanya persepsi dari masyarakat yang dapat menimbulkan stigma positif maupun negatif. Oleh karenanya perlu adanya strategi komunikasi dalam menyampaikan informasi oleh pemerintah kepada masyarakat dan informasi tersebut dapat diterima oleh seluruh masyarakat (Nugraha RG, 2019). Salah satu strategi yang dapat digunakan oleh pemerintah dalam melakukan komunikasi pemerintah yaitu dengan penggunaan media sosial dalam proses komunikasi dengan masyarakat. Selain itu, komunikasi pada saat ini sebagian besar berbasis internet yang mana platform yang dapat digunakan kalau media sosial.

Media sosial merupakan salah satu platform yang digunakan untuk melakukan komunikasi dua arah yang bersifat komunikasi eksternal. Komunikasi eksternal merupakan bentuk penyampaian informasi dari pemerintah kepada publik maupun informasi yang diterima oleh pemerintah dari publik (Kurniawan, 2018). Komunikasi pemerintah melalui media sosial merupakan bentuk komunikasi eksternal karena komunikasi dilakukan untuk memberikan informasi tentang berbagai kebijakan dan peraturan pemerintah kepada masyarakat, organisasi non pemerintah atau swasta. Karena komunikasi di era digital pada saat ini, yang dapat dilakukan melalui media sosial juga menciptakan komunikasi yang multi step communication.

Hadirnya media sosial sebagai platform komunikasi digital mampu memberikan perubahan di dalam instansi yang tadinya komunikasi tersebut bersifat formal akan menjadi informal, sehingga masyarakat juga akan turut fleksibel dalam melakukan komunikasi dengan pemerintah. Selain itu juga adanya media sosial sebagai platform komunikasi dapat menciptakan penyampaian informasi secara efektif dan efisien kepada publik. Perkembangan media sosial yang begitu pesat pun turut memberikan sarana kepada publik dalam mengakses informasi-informasi. Seperti yang dikatakan oleh (Kosasih, 2016), komunikasi akan memberikan pengaruh terhadap hubungan sosial masyarakat dimana akan menimbulkan interaksi masyarakat.

Di era digital pada saat ini, media sosial dapat menjadi sarana yang ideal dan menjadi sumber informasi untuk mengetahui opini publik (Barniat, 2019). Sehingga media sosial memberikan ruang yang tepat dan nyaman untuk menciptakan interaksi sosial antara pemerintah dan public. Akan tetapi di sisi lain, transformasi komunikasi digital ini juga berdampak pada penyebaran informasi yang liar, dimana individu dapat menciptakan informasi yang nantinya akan mempengaruhi pengguna media sosial lainnya. Sehingga, peran pemeirntah diperlukan guna untuk mengontrol arus informasi di media sosial bahwa informasi yang ada tersebut tepat sasaran 
license

dan sesuai kebenarannya atau bukan berita hoax. Seperti pada gambar dibawah ini, bahwasannya (Mergel \& Bretschneider, 2013) menggambarkan hubungan interaksi di media sosial.

Gambar 1. Hubungan Interaksi di Media Sosial

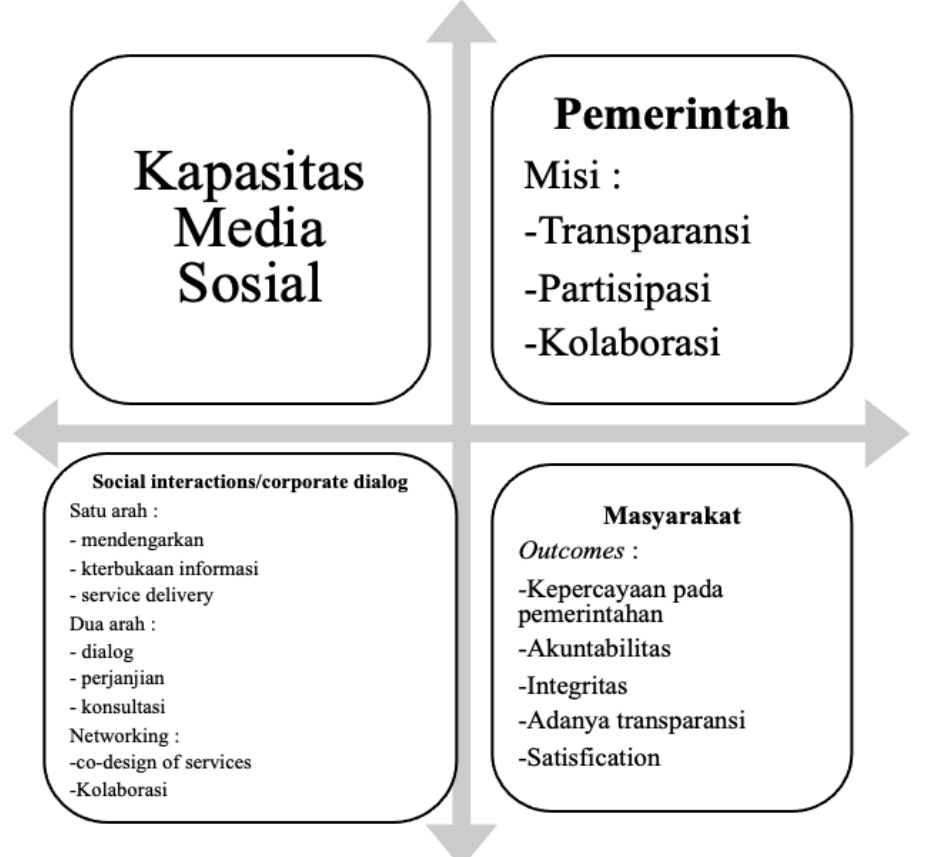

Sumber: (Mergel \& Bretschneider, 2013)

Gambar tersebut menjelaskan bahwa bagi pemerintah, media sosial dapat membantu mencapai tujuan inisiatif pemerintah yang transparan, partisipatif, dan kolaboratif. Salah satu media sosial yang digunakan oleh pemerintah dalam komunikasi adalah Twitter. Twitter dianggap menjadi media komunikasi online yang interaktif, dimana seseorang dengan bebas dapat menyampaikan opini public dan dengan bebas mencipatkan interaksi dengan pengguna lainnya. Seperti yang disampaikan oleh (Liu \& Weber, 2014), penggunaan Twitter akan menciptakan lingkungan yang baik untuk melakukan komunikasi secara terbuka dan tidak terbatas.

Selain itu, Twitter dianggap efektif dalam melakukan komunikasi kepada public karena menurut hasil Wearesosial Hootsuite yang dirilis pada bulan Januari 2019 pengguna media sosial di Indonesia mencapai 150 juta atau sebesar 56\% dari total populasi. Sedangkan 6.43 juta diantaranya adalah pengguna Twitter. Sehingga pada masa pandemi COVID-19 seperti saat ini, komunikasi melalui media sosial Twitter mampu menjadi tempat bertukar informasi yang cepat dan interaktif. Masyarakat dapat dengan cepat mengupdate informasi COVID-19 melalui Twitter, karena berbagai akun baik individu, kelompok, pemerintah maupun akun media pers ikut menyampaikan berbagai informasi terkait dengan COVID-19.

Transformasi komunikasi digital pemerintahan sangat dirasakan ketika adanya pandemi COVID-19. Tidak hanya masyarakat yang dituntut untuk dapat dengan cepat menguasai ICT akan tetapi pemerintah pun turut andil. Di era digital dimana media sosial sebagai salah satu platform komunikasi, maka komunikasi pemerintah tidak cukup hanya menyampaikan informasi. Tetapi perlu dikelola secara terintegrasi melalui pembentukan kolaborasi dan koordinasi antar kementerian/lembaga terkait data dan informasi terkait kebijakan dan rencana lintas departemen. 
Karena pola komunikasi pemerintah yang sebelumnya bersifat formal dan face to face, pada saat ini dapat dialkuakn secara majemuk dan anytime.

Pada masa pandemic COVID-19 saat ini, media sosial salah satunya Twitter dapat menjadi hal yang solutif untuk menciptakan komunikasi pemerintahan. Karena disini pemerintah akan dapat meningkatkan responsivitasnya terhadap situasi yang sedang dihadapi oleh masyarakatnya pada saat ini. Seperti pada penelitian yang dilakukan oleh (Eom et al., 2018a) bahwasannya Twitter dapat dijadikan sebagai jembatan komunikasi antara pemerintah dengan warga negara maupun sebaliknya. Dengan adanya komunikasi di media sosial akan meminimalisir ketimpangan data maupun informasi yang disampaikan oleh sumber lain. Oleh karenanya peran BNPB selaku badan yang bertanggungjawab dalam mengatasi pandemic COVID-19 ini perlu menciptakan komunikasi yang interaktif melalui media sosial Twitter. Dari awal adanya COVID19, melalui akun@BNPB_Indonesia instansi pemerintah tersebut telah aktif menggunakan Twitter untuk menyampaikan berbagai informasi kepada public. Secara khusus desain penelitian ini menunjukkan analisis komunikasi pemerintah melalui media sosial di masa pandemic COVID-19. Dimana akan lebih spesifik untuk mengetahui intensitas komunikasi pemerintah dan hubungan interaksi pemerintah melalui akun Twitter@BNPB_Indonesia. Guna mempermudah bahasan, penelitian ini menggunakan konsep komunikasi pemerintahan dan media sosial.

Menurut Karlfried Knapp, komunikasi adalah interaksi antar orang dengan menggunakan system symbol lingustik, seperti symbol verbal dan non verbal, dimana hal ini dapat disosialisasikan secara langsung atau tatap muka atau melalui media lain (Azmi et al., n.d.). Komunikasi terjadi karena adanya hubungan sosial antar dua orang ataupun lebih dan menciptapkan interaksi sosial (Kosasih, 2016). Sehingga komunikasi sebagai proses penyampaian suatu informasi kepada orang lain baik secara langsung maupun tidak langsung. Komunikasi memiliki konsekuensi terhadap hubungan sosial masyarakat yang dilakukan lebih dari satu orang sehingga akan menimbulkan sebuah interaksi sosial (Kosasih, 2016).

Pemerintah memerlukan komunikasi yang baik dalam penyampaian proses kebijakan dari konsepsi hingga implementasi kebijakan (Gregory, 2006). Komunikasi yang dilakukan antara warga negara atau masyarakat dengan pemerintah, keduanya dapat menjadi sebagai komunikator dimana masyarakat akan menjadi komunikator apabila masyarakat sebagai penggagas ide dan pemerintah sebagai komunikator apabila pemerintah sebagai penyampai informasi (Alfiyani, 2018). Karena komunikasi pemerintahan sebagai penyampai informasi sebuah progam, kebijakan, maupun ide-ide dari pemerintahan untuk menjadi visi dan misi kepada masyarakat (Anggreani et al., 2020). Sehingga komunikasi pemerintahan tidak hanya sebagai sarana atau alat bagi pemerintah untuk menyampaikan dan atau menerima informasi tentang suatu kebijakan publik, misalnya, tetapi juga sebagai sarana memadukan kegiatan-kegiatan secara terorganisasi dalam mewujudkan kerjasama (Silalahi, 2004).

Komunikasi memiliki pengaruh baik terhadap gagasasan, sasaran maupun tugas pemerintahan termasuk dalam menjaga hubungan antara komunikator dan komunikan (Flabianos, 2019). Komunikasi memiliki konsekuensi terhadap hubungan sosial masyarakat yang dilakukan lebih dari satu orang sehingga akan menimbulkan sebuah interaksi sosial (Kosasih, 2016). Komunikasi yang efektif adalah komunikasi yang hasilnya sesuai dengan harapan para pendengarnya atau seseorang yang menerima pesan. Untuk memahami komunikasi yang efektif, dalam paradigma komunikasi yang disampaikan oleh Harold Lasswell , bahwasannya untuk 
menjelaskan komunikasi yaitu dengan menjawab pertanyaan sebagai berikut: who says what in which channel to whom with what effect? Paradigma tersebut menunjukkan bahwa proses komunikasi merupakan pihak komunikator membentuk pesan dan menyampaikannya melalui suatu saluran tertentu kepada pihak penerima yang menimbulkan efek tertentu (Lasswell, 1948).

Komunikasi dapat bekerja secara sistematis sehingga hasilnya dapat sesuai dengan sasaran. Dimana lima elemen pokok komunikasi yaitu komikator/who, pesan/says what, media/in which channel, komunikan/to whom, dan efek/whit what effect tidak boleh ditinggalkam dalam melakukan komunikasi. Sehingga komunikasi akan berjalan baik apabila melewati lima tahap tersebut. Menurut (Abidin, 2016) komunikasi pemerintahan itu dibedakan ke dalam dua bentuk komunikasi berdasarkan fungsinya, yaitu komunikasi internal dan komunikasi eksternal. komunikasi internal merupakan proses komunikasi yang terjadi di dalam organisasi yang dilakukan oleh antar anggota organisasi. Sedangkan komunikasi eksternal merupakan proses penyampaian pesan yang berlangsung oleh organisasi lain atau dengan lingkungannya. Dimana pada dasarnya komunikasi eksternal merupakan bentuk penyampaian informasi dari pemerintah kepada public maupun informasi yang diterima oleh pemerintah dari public. Sehingga dalam komunikasi tersebut terdapat hubungan interaksi antara pemerintah, swasta dan masyarakat (Silalahi, 2004).

Sementara itu media sosial memiliki perkembangan yang cukup pesat dari tahun ke tahun, dimana media sosial pertama kali muncul pada tahun 70an dan mulai berkembang secara signifikan pada tahun 2000 dimana muncul Friendster sebagai media sosial yang dapat terkoneksi (Cahyono, 2016). Seperti yang disampaikan oleh (Trottier \& Fuchs, 2013) bahwasannya media sosial merupakan bentuk komunikasi elektronik dan sebagai situs jaringan yang dapat diikuti oleh seluruh lapisan masyarakat dan pengguna bisa berbagi konten. Sehingga dengan perkembangan media sosial maka akan memberikan dampak terhadap interaksi manusia yang menggunakan media sosial dan bagaimana seseorang akan bertindak.

Media sosial memiliki perkembangan yang cukup pesat dari tahun ke tahun, dimana media sosial pertama kali muncul pada tahun 70an dan mulai berkembang secara signifikan pada tahun 2000 dimana muncul Friendster sebagai media sosial yang dapat terkoneksi (Cahyono, 2016). Seperti yang disampaikan oleh (Trottier \& Fuchs, 2013) bahwasannya media sosial merupakan bentuk komunikasi elektronik dan sebagai situs jaringan yang dapat diikuti oleh seluruh lapisan masyarakat dan pengguna bisa berbagi konten. Sehingga dengan perkembangan media sosial maka akan memberikan dampak terhadap interaksi manusia yang menggunakan media sosial dan bagaimana seseorang akan bertindak.

Pemerintah menjadikan platform media sosial sebagai tempat untuk mengkomunikasikan atas pencapaian yang dilakukan oleh pemerintah atau menciptakan ruang untuk diskusi dengan masyarakat (Belkahla Driss et al., 2019). Karena media sosial dianggap pemerintah sebagai salah satu cara untuk mengumpulkan data maupun opini dari masyarakat (Boudjelida et al., 2016). Sehingga penggunaan media sosial sebagai alat komunikasi pemerintah mampu mengurangi kesenjangan dalam pembuatan kebijakan yang dibuat oleh pemerintah. Hal ini seperti konsep government to citizen (G2C), dimana konsep ini menjadikan sosial media sebagai pendukung untuk membentuk hubungan antara masyarakat dengan pemerintah (Pardo et al., 2012).

Menurut (Lu et al., 2016) terdapat tiga jenis entitas yang terlibat dalam penggunaan media sosial dalam pemerintahan: (1) lembaga pemerintah dan karyawan, yang menggunakan alat media 
sosial untuk informasi pemerintah; (2) layanan media sosial, yang memperluas kemampuan sosial organisasi pemerintah; Dan (3) warga negara dan pemangku kepentingan lainnya, yang terlibat dalam bisnis pemerintah melalui alat media sosial.

\section{Metode}

Penelitian ini menggunakan pendekatan penelitian kualitatif. Dalam (Hakim et al., 2019) metode penelitian kualitatif merupakan salah satu prosedur penelitian yang menghasilkan data deskriptif dalam bentuk ucapan atau tulisan dan perilaku orang-orang yang diamati, sedangkan (Masitoh, 2018) mendefinisikan penelitian deskriptif kualitatif ditujukan untuk mendeskripsikan dan menggambarkan fenomena-fenomena yang ada, baik bersifat alamiah maupun rekayasa manusia, yang lebih memperhatikan mengenai karakteristik, kualitas, keterkaitan antar kegiatan. Pada penelitian ini menggunakan deskriptif kualitatif dengan menganalisis aktifitas komunikasi Badan Nasional Penanggulangan Bencana RI melalui media sosial Twitter, sehingga hal itu dapat menambahkan informasi mendalam untuk pembaca.

Pengumpulan data melalui @BNPB_Indonesia sebagai akun instansi pemerintahan dari Badan Penanggulangan Bencana Nasional RI sebagai salah satu penanggungjawab dalam penanganan COVID-19 di Indonesia. Pemilihan akun ini sebagai bagian untuk melihat aktivitas komunikasi pemerintah dan hubungan interaksi pemerintah melalui akun Twitter@BNPB_RI. Timeline penelitian ini dilihat dari bulan April 2020-November 2020, dimana hal ini dianggap dari awal adanya COVID-19 di Indonesia hingga pandemic besar ini masih berlangsung. Selain itu, artikel ini dapat menganalisis aktivitas komunikasi yang dilakukan oleh pemerintah melalui BNPB RI dalam penanganan COVID-19.

Analisis pada penelitian ini menggunakan software Nvivo 12 Plus pada fitur NCapture. Perangkat lunak NVivo adalah salah satu alat analisis data kualitatif yang digunakan oleh banyak peneliti kualitatif di seluruh dunia (Nofrima et al., 2020). Fitur ini mampu melakukan penarikan data dari media sosial Twitter secara sistematis dan mendalam, selanjutnya dilakukan analisis menggunakan software NVivo 12 Plus dengan beberapa tool seperti cluster analisis yang digunakan untuk mengetahui hubungan actor komunikasi pada penelitian ini dengan nilai minimum korelasi 0.5. Word similarity digunakan untuk melihat komunikasi yang disampaikan oleh actor komunikasi dengan menggunakan pearson correlation. Pearson Correlation merupakan salah satu ukuran korelasi yang digunakan untuk mengukur kekuatan dan arah hubungan linier dari dua veriabel. Selain itu dalam penelitian ini juga menggunakan Teknik analisis Social Network Analysis (SNA) untuk melihat jejaring yang terlibat dalam komunikasi melalui media sosial Twitter. Pada gambar 2, kami membuat desain penelitian untuk menganalisis aktivitas komunikasi pemerintah oleh BNPB dalam komunikasi pemerintah melalui akun media sosial Twitter yaitu@BNPB_Indonesia. 
Gambar 2. Desain Penelitian

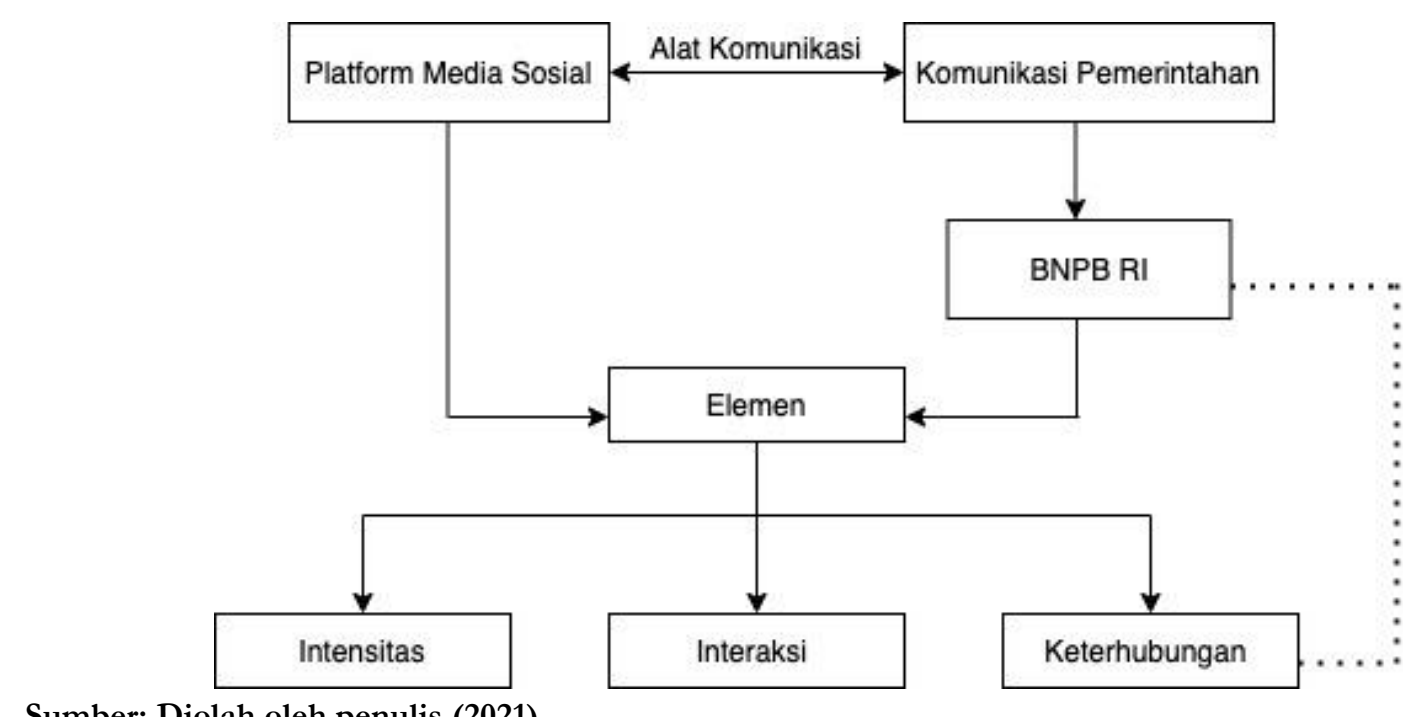

Sumber: Diolah oleh penulis (2021)

\section{Hasil dan Pembahasan}

Komunikasi merupakan hal yang sangat penting di kehidupan masyarakat, komunikasi bisa berkaitan dengan satu orang dengan orang lainnya, suatu kelompok dengan individu, warga negara dengan pemerintah (Encyclopedia, 2019). Sehingga komunikasi tidak dapat dijauhkan dari struktur sosial kehidupan masyarakat. Karena komunikasi menjadi hal penting sebagai proses pertukaran informasi. Apabila melihat dari segi pemeirntah, komunikasi yang dilakukan oleh pemerintah juga menjadi hal yang krusial yang perlu dilakukan. Karena komunikasi pemerintahan sebagai penyampai informasi sebuah progam, kebijakan, maupun ide-ide dari pemerintahan untuk menjadi visi dan misi kepada masyarakat (Anggreani et al., 2020).

Komunikasi memiliki pengaruh baik terhadap gagasasan, sasaran maupun tugas pemerintahan termasuk dalam menjaga hubungan antara komunikator dan komunikan (Flabianos, 2019). Selain itu, komunikasi memiliki konsekuensi terhadap hubungan tatanan sosial yang nantinya akan terbangun hubungan interaksi. Oleh karenya perlu adanya strategi komunikasi pemerintah untuk membangun komunikasi yang efektif. Komunikasi yang efektif adalah komunikasi yang hasilnya sesuai dengan harapan para pendengarnya atau seseorang yang menerima pesan. Untuk memahami komunikasi yang efektif, dalam paradigma komunikasi yang disampaikan oleh Harold Lasswell , bahwasannya untuk menjelaskan komunikasi yaitu dengan menjawab pertanyaan sebagai berikut: who says what in which channel to whom with what effect? Paradigma tersebut menunjukkan bahwa proses komunikasi merupakan pihak komunikator membentuk pesan dan menyampaikannya melalui suatu saluran tertentu kepda pihak penerima yang menimbulkan efek tertentu (Lasswell, 1948).

Salah satu strategi komunikasi pemerintah untuk menciptakan hubungan interaksi yang efektif, pemerintah dapat membangun sebuah komunikasi melalui media sosial. Karena media sosial memiliki potensi untuk meningkatkan akses warga terhadap informasi pemerintah dan dengan demikian mengurangi asimetri informasi antara fungsionaris pemerintah dan warga negara (Eom et al., 2018). Seperti yang dikatakan oleh (Mergel \& Bretschneider, 2013) bagi pemerintah media sosial membantu mencapai tujuan inisiatif pemerintah yang terbuka, transparansi, partisipasi, dan kolaborasi. 
Hal tersebut juga sama dengan hasil penelitian yang dilakukan oleh (Eom et al., 2018a) bahwasannya melalui Twitter walikota Seoul, mampu dijadikan sebagai jembatan komunikasi antara pemerintah dengan warga negara maupun sebaliknya. Dimana peran walikota sebagai pusat menjembatani dalam jaringan Twitter berkontribusi untuk meningkatkan responsivitas pemerintah dengan memungkinkan untuk mengatasi pemutusan hubungan antara warga negara dan pemerintah daerah, dan asimetri informasi di antara walikota, pejabat publik, dan warga negara. Sehingga dari hasil penelitian tersbeut dapat dikatakan media sosial dapat berfungsi sebagai platform komunikasi pemerintah yang dilakukan kepada warga negaranya.

Selain itu penelitian yang dilakukan oleh (Chen et al., 2020) terkait dengan media sosial sebagai platform untuk memberikan informasi secara cepat dan menjadi ruang public untuk dapat memberikan opini secara bebas. Hal ini lah yang dapat menciptakan ketegangan antar pengguna media sosial. Oleh karenanya, komunikasi pemerintah menjadi penengah untuk dapat mencairkan suasana dan mengklarifikasi informasi yang ada. Penelitian yang dilakukan oleh (Rahmawati \& Pratiwi, 2020) bahwasannya komunikasi pemerintah melalui media sosial bersifat cepat, interaktif dan massif dan tidak berjarak sehingga komunikasi pemerintah melalui media sosial tepat dilakukan di masa pandemi.

Komunikasi pemerintah melalui media sosial juga dapat menjadi solusi dalam melakukan krisis komunikasi. Hal ini dapat menjadi solusi, seprti pada saat ini dimana dengana danya pandemic COVID-19, pemerintah terhambat dalam membangun komunikasi secara langsung. Sehingga platform media sosial menajdi urgensi untuk membangun komunikasi di tengah pandemic ini. Seperti penelitian yang dilakukan oleh (Malecki et al., 2020) pemerintah perlu melakukan komunikasi secara informatif di masa pandemi COVID-19 guna untuk meminimalisir ketimpangan data maupun informasi yang disampaikan oleh sumber lain.

\section{Intensitas Twitter@BNPB_Indonesia Dalam Komunikasi Pemerintahan di Masa Pandemi COVID-19}

Media sosial sejatinya sebagai media interaksi dan sosialisasi. Sehingga pada saat ini wajar apabila media sosial dijadikan media komunikasi pemerintahan. Oleh karenanya hal inilah yang menarik perhatian bagi pemerintahan untuk membangun interaksi kepada masyarakat. Selain itu menurut (Liu \& Weber, 2014) penggunaan Twitter tidak hanya untuk membentuk hubungan saja, akan tetapi banyak orang menggunakan Twitter untuk terlibat aktif dalam diskusi tentang masalah kontrevesial.

Penggunaan media sosial juga menjadi alternatif ketika berada dalam krisis komunikasi. Seperti penelitian yang dilakukan oleh (Graham et al., 2015) bahwasannya penggunaan media sosial di tingkat pemerintah local menujukkan masih minim, padahal hal ini perlu dilakukan oleh pemerintah untuk adopsi dan penggunaan alat media sosial untuk komunikasi krisis dan bagian media sosial dalam mengelola krisis. Sehingga peran media social memang memiliki urgensi sebagai alat untuk komunikasi.

Seperti di masa pandemic COVID-19 seperti saat ini, bahwasannya komunikasi melalui media sosial khususnya Twitter akan menajdi jalan alternatif yang dilakukan oleh pemerintah. Dan hal ini telah dilakukan oleh Badan Penanggulangan Bencana Nasional Republik Indonesia melalui akun Twitter@BNPB_Indonesia, bahwasannya di masa pandemic COVID-19 BNPB membangun hubungan interaksi melalui media sosial Twitter. Seperti terlihat pada gambar dibawah, terlihat intensitas Tweet melalui akun@BNPB_Indonesia. 
Gambar 3. Intensitas Twitter Akun@BNPB_Indonesia

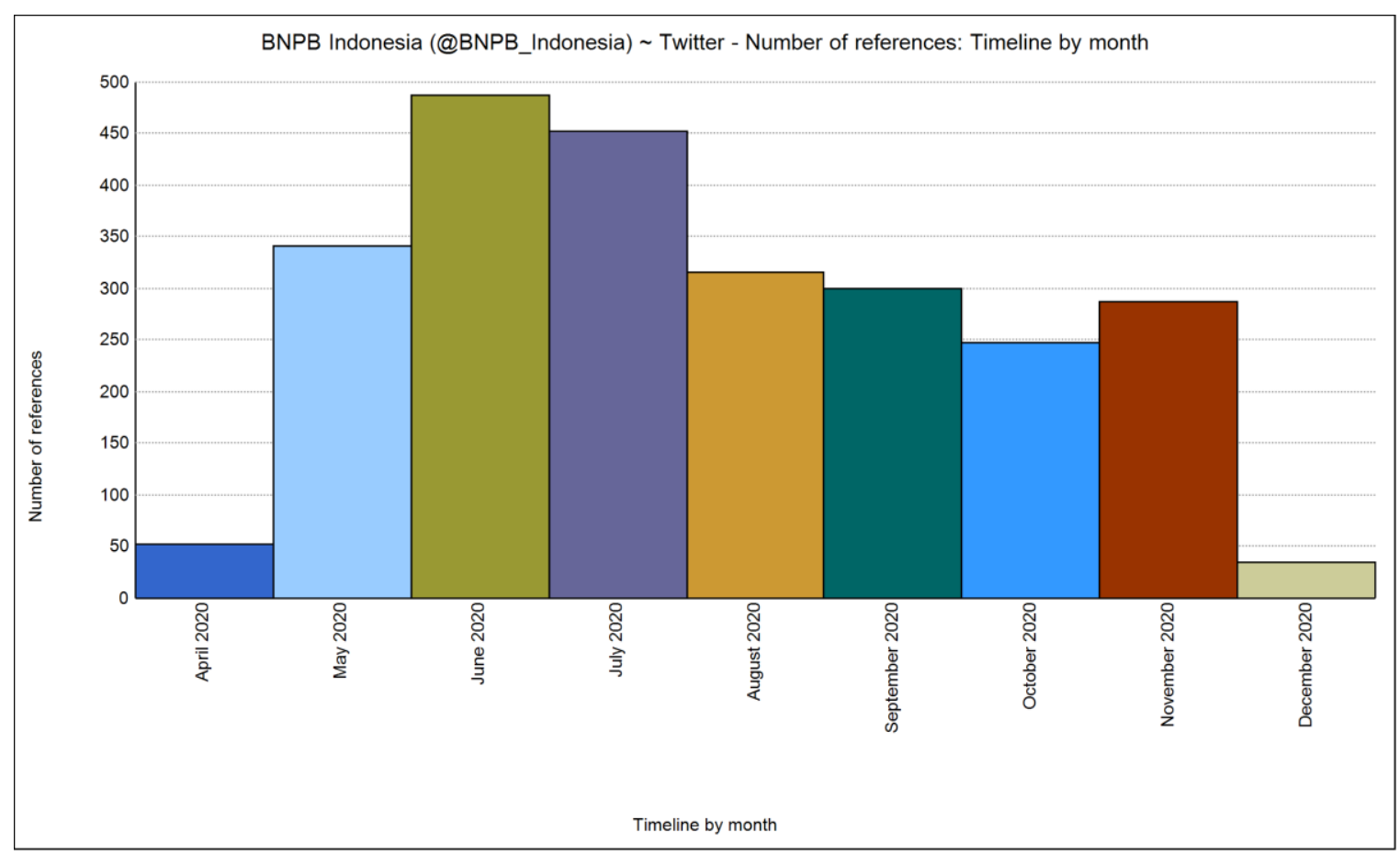

Sumber: Diolah oleh penulis dengan NVivo 12 Plus

Dari gambar 3 di atas, terlihat intensitas penggunaan Twitter melalui akun @BNPB_Indonesia. Bahwasannya di masa pandemic COVID-19, penggunaan Twitter oleh BNPB mengalami peningkatan. Hal ini terlihat bahwasannya pada rentang waktu April 2020 hingga Juli 2020 bahwa Twitter@BNPB_Indonesia selalu mengalami peningkatan intensitas. Peningkatan intensitas komunikasi yang dilakukan oleh BNPB juga adanya peningkatan kasus yang terkonfirmasi di Indonesia. Dan intensitas Twitter@BNPB_Indonesia pada bulan April memiliki presentase 10\%, bulan Mei pada 69,6\%, pada bulan Juni 2020 dengan jumlah presentase 97,4\%, bulan Juli memiliki presentase 90\%, pada bulan Agustus intensitas Twitter BNPB memiliki penurunan di angka $62 \%$, pada bulan September memiliki presentase $60 \%$, di bulan Oktober turun menjadi $50 \%$, dan pada bulan November mengalami peningkatan intensitas tweet yang dilakukan oleh BNPB dengan angka presentase 58\%.

Intensitas Twitter yang dilihat dari bulan April hingga Juli 2020 mengalami peningkatan juga didukung dengan peningkatan kasus COVID-19 yang telah terkonfirmasi (lihat gambar 4). Sehingga hal ini menjadi penyebab akun@BNPB_Indonesia menyampaikan informasi melalui Twitter dengan intens kepada masyarakat. Hal ini juga seperti dilansir dalam surat kabar Kompas, dimana kasus baru harian mengalami peningkatan yang cukup signifikan apabila dibandingkan dengan kasus yang ada pada bulan sebelum-sebelumnya dengan jumlah 1.241 pada awal Bulan Juni (Kompas.com, 2020). Sehingga hal ini juga memiliki keterhubungan dengan adanya peningkatan intensitas tweet yang dilakukan oleh akun@BNPB_Indonesia. 


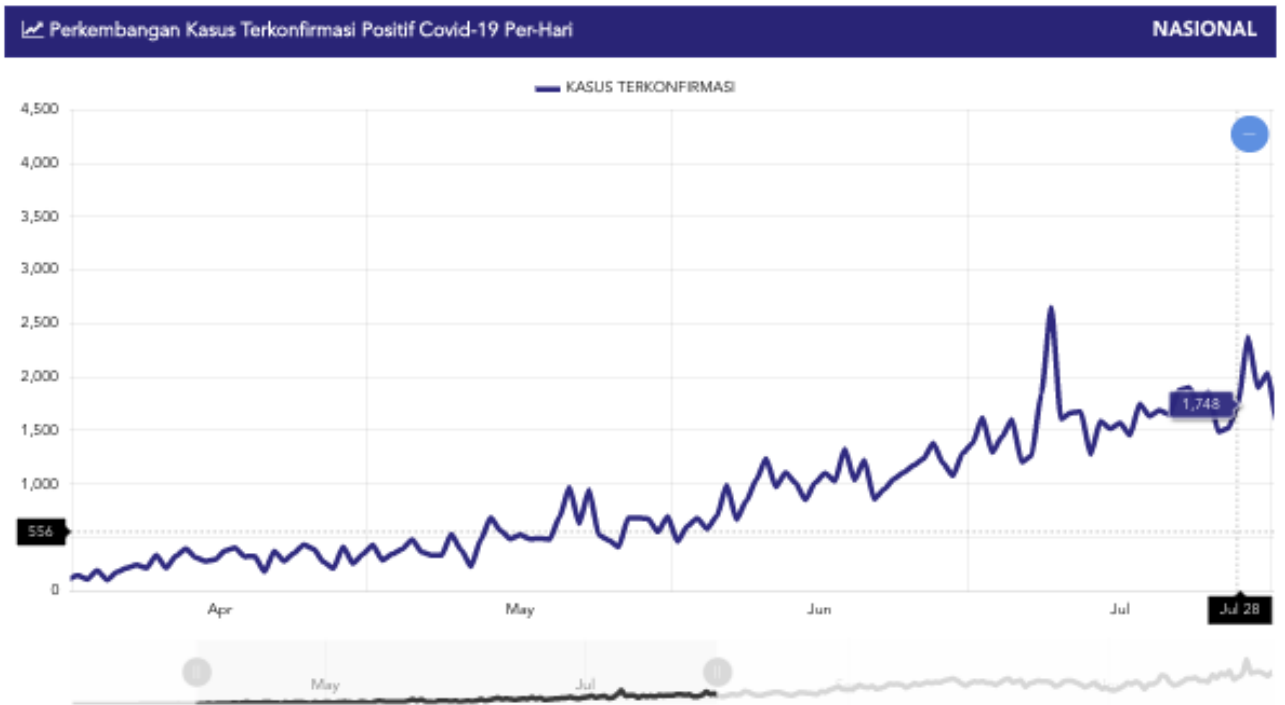

\section{Sumber: https://covid19.go.id/peta-sebaran}

Dari gambar peningkatan kasus COVID-19 yang terkonfirmasi di atas, perlu adanya peran pemerintah untuk melakukan komunikasi kepada masyarakat terkait dengan penanganan COVID-19 sangat perlu dilakukan. Oleh karenanya, melalui akun @BNPB_Indonesia, pemerintah meningkatkan intensitas komunikasinya melalui media sosial Twitter kepada masyarakat. Hal ini guna untuk memberikan informasi kepada masyarakat sebagai himbauan dalam membantu memutus rantai penyebaran virus COVID-19 di Indonesia. Melalui akun @BNPB_Indonesia, pemerintah menyampaikan berbagai informasi terkait dengan infografis penyebaran kasus, himbauan kepada masyarakat, kebijakan pemerintah serta informasi terkait dengan penanganan COVID-19 di Indonesia.

Komunikasi yang efektif yang dilakukan oleh pemerintah di masa pandemic akan menjadi efektif karena hal ini akan menjadi salah satu bentuk proteksi dalam hal upaya pencegahan dan penanggulangan terhadap semakin menyebarnya virus Corona tersebut. Selain itu, menurut (Indasari \& Anggriani, 2020) hal tersebut sebagai komunikasi krisis yang perlu dilakukan untuk meningkatkan kepercayaan masyarakat terhadap adanya disinformasi yang terjadi di masa krisis yang dapat menimbulkan berbagai perspektif yang berbeda di masyarakat.

Dari hasil penelitian, dapat diketahui bahwasannya intensitas akun Twitter @BNPB_Indonesia di masa pandemic COVID-19 dalam membangun komunikasi pemerintah telah menciptakan komunikasi yang efektif. Dimana pemerintah telah berupaya untuk terus meningkatkan penyebaran informasi terkait dengan penanganan COVID-19 kepada publik. Dengan tingkat intensitas komunikasi yang tinggi melalui media sosial, maka hal ini dapat menciptakan transparansi informasi pemerintah terkait dnegan COVID-19. Sehingga hal ini juga dapat menciptakan tingkat kepercayaan masyarakat kepada pemerintah di masa pandemic COVID-19. Hal ini seperti penelitian yang dilakukan oleh (Graham, 2014; Malecki et al., 2020) bahwasannya penggunaan media sosial di lingkup pemerinta perlu dilakukan dalam krisis komunikasi dan hal ini dapat meminimalisir ketimpangan informasi dari sumber lain. 
license

\section{Hubungan Interaksi Akun Twitter @BNPB_Indonesia di Masa Pandemi COVID-19}

Adanya pandemic COVID-19 di dunia khususnya di Indonesia mampu merubah pola tatanan kehidupan manusia, salah satunya pola interaksi masyarakat. Pada masa pandemi COVID-19 manusia lebih kerap melakukan interaksi melalui virtual dengan media sosial, salah satunya Twitter. Media ini menjadi alternatif bagi manusia untuk tetap saling terhubung dalam membangun komunikasi dua arah. Melalui media sosial dapat menghubungkan antar orang dalam skala kecil maupun skala besar (Suryandari \& Lutviana, 2020).

Pemerintah perlu membangun hubungan interaksi dalam melakukan komunikasi di media sosial di masa pandemic COVID-19 terkait dengan pemberitaan maupun informasiinformasi mengenai pandemic COVID-19. Karena informasi dari pemerintahan yang rutin diberikan mampu memberikan sosialisasi dan pemahaman kepada masyarakat. Sehingga masyarakat pun nantinya akan ikut berbagi informasi dengan individu lainnya. Sehinngga nantinya informasi yang diperoleh oleh masyarakat melalui media sosial, dapat disebarluaskan secara langsung dnegan adnaya pemahaman terkait COVID-19. Karena hal ini akan menjadi komunikasi yang efektif dan dapat membantu dalam upaya penanganan pemutusan rantai penyebaran COVID-19 (Pratiwi \& Hidayat, 2020).

Menurut (yuliana, 2019) bahwasannya komunikasi melalui media sosial berbentuk komunikasi daring dan hal ini akan menciptakan suatu group, cluster maupun cohesive subgroups. Sehingga dengan adanya interaksi pemerintah melalui media sosial di masa pandemic COVID-19 juga mampu menciptakan suatu cluster dimana ini nantinya akan membantu untuk mengetahui respon dari public. Melalui olah data dengan NVivo 12 Plus, maka diketahui hubungan interaksi komunikasi yang dilakukan oleh pemerintah melalui akun@BNPB_Indonesia di Twitter sebagai berikut:

Gambar 5. Interaksi Akun Twitter@BNPB_Indonesia

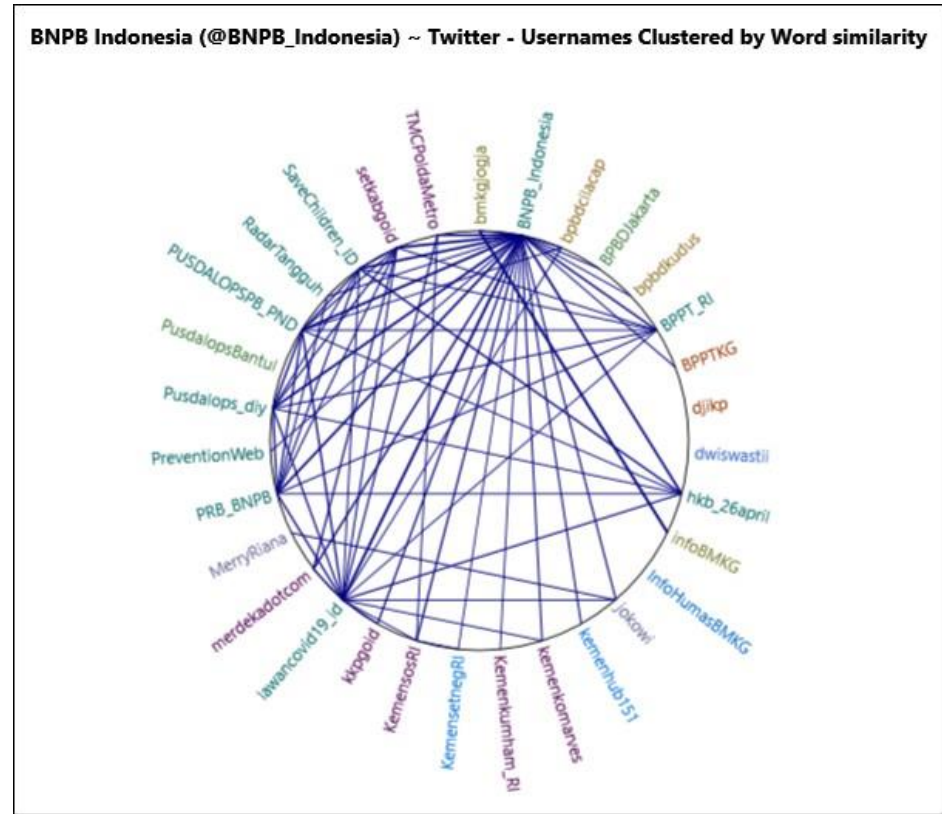

\section{Sumber: Diolah oleh penulis dengan NVivo 12 Plus}

Dari gambar diatas dapat dilihat, bahwasanya pemerintah melalui akun @BNPB_Indonesia melakukan komunikasi melalui media sosial Twitter membangun interaksi dengan beberapa akun Twitter lainnya seperti organisasi pemerintah lainnya, tokoh negara, maupun kelompok komunitas. Seperti adanya interaksi dengan akun Presiden Republik 
license

Indonesia melalui akunnya@Jokowi serta beberapa instansi pemerintah baik pusat maupun daerah yaitu@KemensosRI, @Kemenkuham_RI, @Kemenhub151, @Pusdalops_diy, @Pusdalopsbantul,@BPBDJakarta,@BPBDCilacap serta dengan komunitas yang muncul ketika COVID-19 yaitu dengan akun@lawancovid19_id. Dengan adanya interaksi yang tercipta ini mampu mengurangi adanya misinformasi kepada public. Karena sejak adanya pandemic di Indonesia keraps kelai ditemukan informasi-informasi yang tidak signifikan dan bersifat hoax, sheingga hal ini akan memacu ketegangan di public. Oleh karenanya dengan komunikasi yang dilakukan oleh pemerintah melalui akun@BNPB_Indonesia dan membangun interaksi antar actor hal ini akan meningkatkan kepercayaan masyarakat Kembali kepada pemerintah.

Dalam situasi krisis seperti pada masa pandmei COVID-19 ini, komunikasi krisis memang perlu dibangun. Menurut (Damayanti \& Yuriawan, 2020) terdapat beberapa prinsip komunikasi yang perlu diperhatikan agar mencipatakan komunikasi yang berhasil yaitu (1) mengenali audien, (2) melibatkan pakar, (3) menciptakan keahlian dalam berkomunikasi, (4) menjadi sumber informasi yang dapat dipercaya, (5) tanggung jawab bersama, dan (6) menjamin keterbukaan. Platform media sosial Twitter salah satu meida yang teapt dalam menyampaikan informasi di kalangan masyarakat, karena intensitas penggunanya yang besar sehingga intensitas penyebaran informasi pun akan luas.

Gambar 6. Keterhubungan Akun Pemerintah

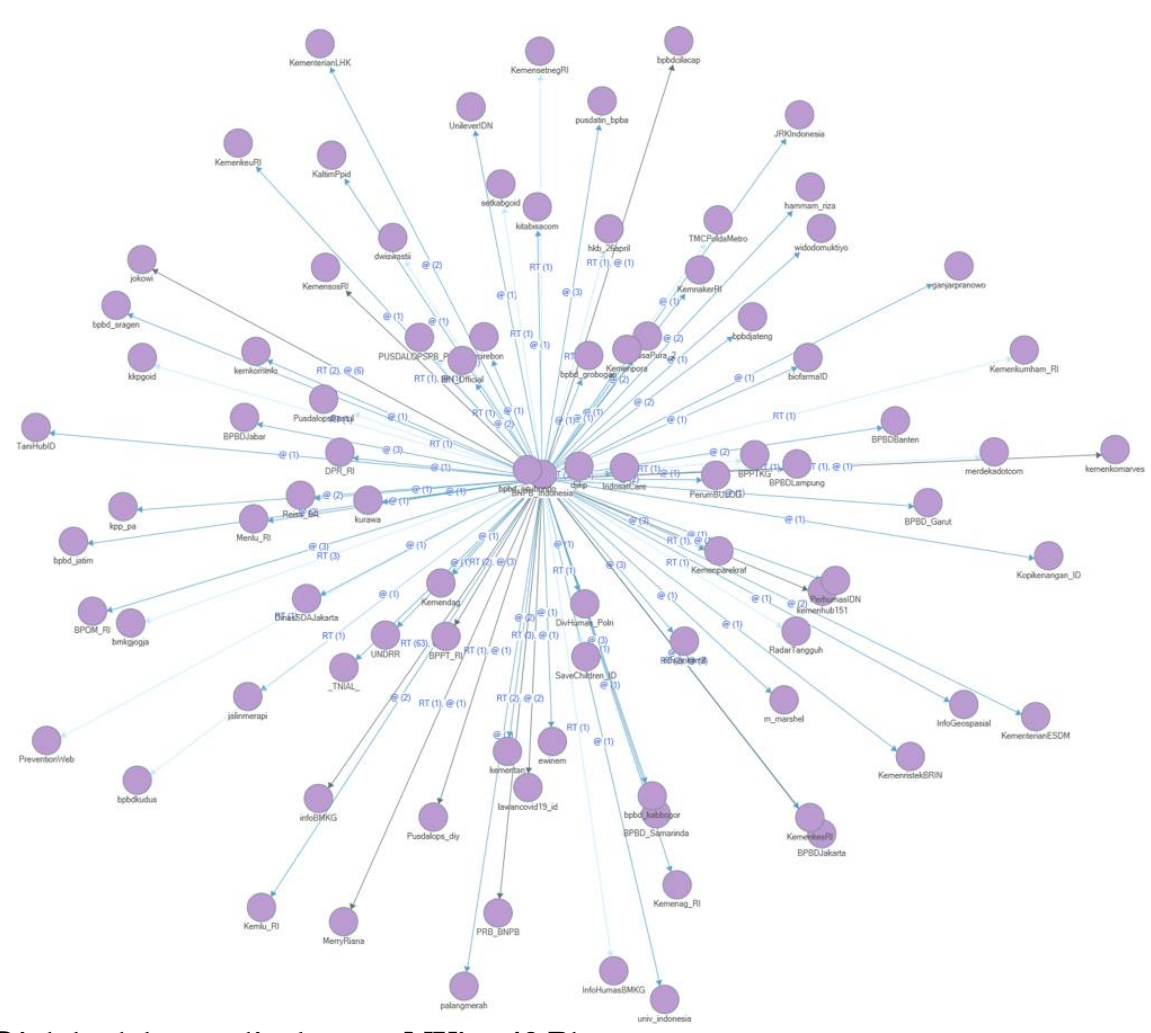

Sumber: Diolah oleh penulis dengan NVivo 12 Plus

Dari gambar diatas, terlihat bahwasannya keterhubungan penyebaran informasi melalui akun@BNPB_Indonesia berhasil diterima oleh pengguna Twitter lainnya atau masyarakat. Hal ini terlihat pada gambar sosiogram di atas, bahwasannya informasi melalui @BNPB_Indonesia mendapat respon dan ikut disebarluaskan oleh public. Karena dengan media sosial pengguna dapat dengan mudah berpartisipasi,berbagi dan membuat konten. Sehingga media sosial Twitter 
dapat menjadi solusi komunikasi pemerintahan dalam keadaan krisis. Dimana hal ini nantinya akan disebut sebagai komunikasi krisis, yaitu pertukaran informasi yang dilakukan real time, dan mampu membuka ruang untuk berbagai saran dan pendapat secara cepat ketika keadaan sedang mengalami ancaman seperti ancaman kesehatan pada masa pandemic COVID-19.

\section{Kesimpulan}

Peran media sosial menjadi penting dalam membangun komunikasi antar aktor. Terlebih seperti pada masa pandemic COVID-19. Komunikasi dari pemerintah perlu dilakukan secara cepat dan teapt sasaran. Hal ini guna untuk mengurangi disinformasi maupun misinformasi kepada public. Karena dengan melihat keadaan seperti saat ini, kerap adanya informasi-informasi tentang COVID-19 yang menimbulkan ketegangan antar actor di media sosial. Sehingga komunikasi pemerintah melalui media sosial menjadi penting dilakukan segera mungkin untuk dapat memberikan kejalasan informasi-informasi tentang COVID-19. Tidak hanya itu, komunikasi pemerintah melalui media sosial juga dapat membangun tingkat kepercayaan masyarakat kepada langkah pemerintah. Selain itu juga, informasi-informasi yang disampaikan oleh pemerintah juga memberikan sosialisasi serta pengetahuan bagi masyarakat. Sehingga masyarakat yang menerima informasi tersebut dapat membantu menyebarluaskan kepada individu lain dengan adanya pemahaman tentang COVID-19.

Komunikasi yang dibangun melalui media sosial Twitter juga menciptakan suatu hubungan interaksi. Hal ini lah yang akan mengahasilkan komunikasi pemerintah yang efektif. Karena dengan adanya keterhubungan melihatkan bahwasannya antar pengguna saling membutuhkan dan tertarik akan informasi yang disampaikan oleh@BNPB_Indonesia. Dengan demikian, komunikasi yang dibangun oleh pemerintah di masa pandemic COVID-19 melalui akun Twitter@BNPB_indonesia aktif menyampaikan informasi kepada public dan informasi tersebut dapat diterima oleh public dengan baik. Sehingga hal ini melihatkan komunikasi pemerintah yang bersifat eksternal dimana memiliki fungsi to managing people. Kajian ini masih memiliki kekurangan, sehingga masih perlu adanya penelitian lebih lanjut terkait dengan komunikasi krisis yang dibangun oleh pemerintah.

\section{Referensi}

Abidin, Y. Z. (2016). Komunikasi Pemerintahan Filosofi, Konsep dan Aplikasi. CV Pustaka Setia. Alfiyani, N. (2018). Media Sosial Sebagai Strategi Komunikasi Politik. Potret Pemikiran, 22(1). https://doi.org/10.30984/pp.v22i1.762

Anggreani, M. D., Purnomo, E. P., \& Kasiwi, A. N. (2020). RUANG PUBLIK VIRTUAL SEBAGAI PINTU KOMUNIKASI GOVERNMENT TO CITIZEN (Studi Kasus: Perbandingan Media Sosial Pemerintah Kota Yogyakarta dan Surabaya). Jurnal MODERAT, 6(1), 203-220. https://jurnal.unigal.ac.id/index.php/moderat/article/view/3165/2919

Anisa, R., \& Rachmaniar, R. (2019). Media Informasi dan Komunikasi Pemerintah Provinsi jawa Barat. Jurnal Lontar, 7(1), 36-40.

Azmi, O., Anisasari, Z., \& Uny, F. I. S. (n.d.). POLA KOMUNIKASI ANTARA PEMERINTAH DAN ORGANIS ASI KEPEMUDAAN TINGKAT KABUPATEN SLEMAN. 1-15. 
Barniat, Z. (2019). POLITICAL COMMUNICATIONS IN THE SOCIAL MEDIA OF INDUSTRIAL REVOLUTION 4.0. Konsensus, 1(1), 59-67.

Chen, E., Lerman, K., \& Ferrara, E. (2020). Tracking Social Media Discourse About the COVID-19 Pandemic: Development of a Public Coronavirus Twitter Data Set. JMIR Public Health and Surveillance, 6(2), e19273. https:/ / doi.org/10.2196/19273

Damayanti, A., \& Yuriawan, K. (2020). Instagram sebagai Medium Komunikasi Risiko di Masa Pandemi COVID-19: Studi Netnografi terhadap Komunitas Online KawalCOVID19. id Instagram as a Medium of Risk Communication in COVID-19 Pandemic: A Netnography Study of Virtual Community KawalCOVID19 . i. 18(02), 176-193. https://doi.org/10.46937/18202032355

Encyclopedia. (2019). 済無No Title No Title. Journal of Chemical Information and Modeling, 53(9), 1689-1699. https://doi.org/10.1017/CBO9781107415324.004

Eom, S. J., Hwang, H., \& Kim, J. H. (2018a). Can social media increase government responsiveness? A case study of Seoul, Korea. Government Information Quarterly, 35(1), 109_ 122. https://doi.org/10.1016/j.giq.2017.10.002

Eom, S. J., Hwang, H., \& Kim, J. H. (2018b). Can social media increase government responsiveness? A case study of Seoul, Korea. Government Information Quarterly, 35(1), 109122. https://doi.org/10.1016/j.giq.2017.10.002

Erliana, H. (2014). Paradigma Komunikasi Pemerintahan. Jurnal Komunikasi Pemerintahan, 54.

Fauzi, E., \& Rahmawati, D. E. (2019). Government of Yogyakarta City Communication in the Arrangement of Maliboro Areas in 2015-2016. Advances in Social Science, Education, and Humanities Research, 353(IcoSIHESS), 2016-2018. https://doi.org/10.2991/icosihess19.2019 .48

Flabianos, H. (2019). PENGARUH KOMUNIKASI PEMAS ARAN POLITIK PARTAI SOLIDARITAS INDONESIA MELALUI MEDIA SOSLAL INSTAGRAM PADA PEMILU 2019 THE INFLUENCE OF INDONESLAN SOLID ARITY PARTY POLITICAL MARKETING COMMUNICATIONS THROUGH INSTAGRAM SOCIAL MEDIA IN 2019 ELECTION. 3-4.

Graham, M. W. (2014). Government communication in the digital age: Social media's effect on local government public relations. Public Relations Inquiry, 3(3), 361-376. https://doi.org/10.1177/2046147X14545371

Graham, M. W., Avery, E. J., \& Park, S. (2015). The role of social media in local government crisis communications. Public Relations Review, 41(3), 386-394. https://doi.org/10.1016/j.pubrev.2015.02.001

Gregory, A. (2006). A development framework for government communicators. Journal of Communication Management, 10(2), 197-210. https://doi.org/10.1108/13632540610664742

Hakim, A. R., Zaenuri, M., \& Fridayani, H. D. (2019). Collaborative governance in managing educative tourism of jogja exotarium in sleman regency 2019. Journal of Governance and Public Policy, 6(2), 195-215.

Indasari, F., \& Anggriani, I. (2020). KRISIS KOMUNIKASI PADA MASA PANDEMI COVID-19 (Studi Kasus Pemberitaan Penyebaran COVID-19 melalui Udara). Profesional: Jurnal Komunikasi Dan Administrasi Publik, 7(1), 1-11. https://doi.org/10.37676/professional.v7i1.1086

Kompas.com. (2020). Tren Kasus COVID-19 Meningkat di Bulan Juni, Ini Alasannya Menurut Abli. Kompas.Com. https://www.kompas.com/tren/read/2020/06/17/200500665/tren-kasusCOVID-19-meningkat-di-bulan-juni-ini-alasannya-menurut-ahli?page=all

Kosasih, I. (2016). PERAN MEDIA SOSIAL FACEBOOK DAN TWITTER DALAM MEMBANGUN KOMUNIKASI (Persepsi dan Motifasi Masyarakat jejaring Sosial Dalam Pergaulan). Journal of Chemical Information and Modeling, 53(9), 1689-1699. https://doi.org/10.1017/CBO9781107415324.004 
license

Kurniawan, D. (2018). Komunikasi Model Laswell Dan Stimulus-Organism-Response Dalam Mewujudkan Pembelajaran Menyenangkan. Jurnal Komunikasi Pendidikan, 2(1), 60. https://doi.org/10.32585/jkp.v2i1.65

Lasswell, H. (1948). The structure and function of communication in society. İletisim Kuram ve Araștorma Dergisi, 1948, 215-228.

Liu, Z., \& Weber, I. (2014). Is Twitter a public sphere for online conflicts? a cross-ideological and cross-hierarchical look. Lecture Notes in Computer Science (Including Subseries Lecture Notes in Artificial Intelligence and Lecture Notes in Bioinformatics), 8851, 336-347. https://doi.org/10.1007/978-3-319-13734-6_25

Malecki, K. M. C., Keating, J. A., \& Safdar, N. (2020). Crisis Communication and Public Perception of COVID-19 Risk in the Era of Social Media. Clinical Infectious Diseases, 53726(Xx), 1-6. https://doi.org/10.1093/cid/ciaa758

Masitoh, S. (2018). Strategi Komunikasi Eksternal Humas Polda D.I.Yogykarta Dalam Mengelola Citra Positif Institusi. Student Journal of Communication (SJC), 1(1).

Mergel, I., \& Bretschneider, S. (2013). A Three-Stage Adoption Process for Social Media Us. Public Administration Review, 73(June), 390-400. https://doi.org/10.1111/puar.12021.390

Nofrima, S., Nurmandi, A., Dewi, D. K., \& Salahudin. (2020). Cyber-activism on the dissemination of \# Gejayanmemanggil : Yogyakarta's student movement. Jurnal Studi Komunikasi, 4(1, March), 103-116. https://doi.org/10.25139/jsk.v4i1.2091.Received

Nugraha RG. (2019). Pelaksanaan Strategi Komunikasi Pemerintah Indonesia Dalam Penanggulangan Hoax. Jurnal Informatika. Universitas Telkom. Diakses Pada Hari Selasa 30 Juli 2019. Pukul 16:42 WIB., 6(1), 1568-1578.

Pratiwi, S. A., \& Hidayat, D. (2020). Iklan Layanan Masyarakat COVID-19 Di Media Sosial dan Perilaku Masyarakat di Jawa Barat. 1-7.

Rahmawati, D. E., \& Pratiwi, V. P. (2020). Aktifitas Komunikasi Pemerintah DIY melalui Twitter pada Masa Pandemi COVID-19. In Covid 19 dalam Perspektif Governance (pp. 172195). Samudra Biru.

Silalahi, U. (2004). Komunikasi Pemerintahan : Mengirim Dan Menerima Informasi Tugas Dan Informasi Publik. Jurnal Administrasi Publik Unpar, 3(1), 36-54.

Suryandari, N., \& Lutviana, V. (2020). Impression management of buzzer in social media Twitter. Jurnal Studi Komunikasi (Indonesian Journal of Communications Studies), 4(3), 614. https://doi.org/10.25139/jsk.v4i3.2665

yuliana, irma. (2019). Adopsi Social Network Analysis (Sna) Dalam Upaya Membangun Ketangguhan Bencana Di Masyarakat. JIKO (Jurnal Informatika Dan Komputer), 2(2), 49-54. https://doi.org/10.33387/jiko.v2i2.1312 